\title{
JUDAISM, PROCESS THEOLOGY, AND FORMAL AXIOLOGY: A PRELIMINARY STUDY
}

\author{
Rem B. Edwards
}

REM B. EDWARDS is Lindsay Young Professor of Philosophy Emeritus at the University of Tennessee. His most recent books are John Wesley's Values - And Ours (2012), Spiritual Values and Evaluations (2012) and An Axiological Process Ethics (2014). He has published 21 books and over 90 articles and reviews. For more details, please visit: https://sites.google.com/site/rembedwards. His e-mail address is: remb1@comcast.net.

\begin{abstract}
This article approaches Judaism through Conservative Rabbi Bradley S. Artson's book, God of Becoming and Relationships: The Dynamic Nature of Process Theology. It explores his understanding of how Jewish theology should and does cohere with central features of both Process Theology and Robert S. Hartman's Formal Axiology. These include the Axiological/Process concept of God, the intrinsic value and valuation of God and unique human beings, and Jewish extrinsic and systemic values, value combinations, and value rankings.
\end{abstract}

\section{Introduction}

Jewish literature on spirituality and ethics is exceedingly vast. In the interest of manageability, this discussion will concentrate on Judaism as understood and explained in Rabbi Bradley S. Artson's book, God of Becoming and Relationships: The Dynamic Nature of Process Theology. When my Jewish friend, Marcos Gojman, in Mexico City, learned that I had published my book on An Axiological Process Ethics early in 2014, he recommended Rabbi Artson's excellent book to me. I further recommend it to anyone who is interested in harmonizing Judaism with the Process Theology derived from Alfred North Whitehead, Charles Hartshorne, John B. Cobb, Jr., and many others. I studied with Hartshorne and Cobb at Emory University in the 1950s and early 1960s, and I have been convinced by some version of Process Theology ever since. As Rabbi Artson points out (xx), most of the work on Process Theology has been done by Protestant Christian theologians and philosophers, but he clearly recognizes and explains the importance, fruitfulness, and applicability of 
process thought to Judaism. He also develops relevant themes with great clarity and persuasiveness in his book, and he indicates that many other prominent Jewish theologians are now integrating process thinking into Jewish theology (xxi). An internet search for "Judaism and Process Theology" will further confirm this claim.

Artson concentrates on Judaism and Process Theology. This article will explore that and further accentuate those aspects of his understanding of Judaism that harmonize well with the Formal Axiology of Robert S. Hartman. It will summarize the main features of Artson's emphasis on God in process. Robert S. Hartman himself had a Jewish father, a Lutheran mother, and was raised by a Roman Catholic stepmother, so I believe that he would have been very much interested in this discussion.

\section{The Intrinsic Value and Evaluation of God}

Robert S. Hartman distinguished three kinds of goodness. Intrinsically good individuals like God, people, and animals are ends in themselves, valuable for their own sakes. Extrinsically good things like cars, chairs, and moral actions are useful means to ends beyond themselves. Systemically good formalities like thoughts, beliefs, ideals, rules, and ritual forms are mental or conceptual values. Each kind of goodness can be evaluated in three corresponding ways-intrinsically with singular personal concepts and intense feelings, extrinsically with everyday sensory concepts and ordinary feelings, and systemically with constructs or definitions and with minimal feelings that do not interfere with rational objectivity and impartiality. Each kind of value can also be evaluated as if it were some other kind of value. For example, people can be evaluated as if they were mere things, or mere ciphers in ideological systems. Although he does not use Hartman's language of intrinsic, extrinsic, and systemic values and evaluations, much that Rabbi Artson has to say can be reexpressed and fruitfully understood using that terminology.

Considered axiologically, God is the One Supreme Intrinsically Valuable Reality, an end in himself, infinitely valuable for his own sake. Rabbi Artson does not use exactly those words, but he does make it clear on many pages that God is both lovable and loving, and that we should relate to God with our own love. Axiologically understood, God is the supreme intrinsic good, and we should evaluate God intrinsically. Artson explains that the Jewish God is full of goodness, grace, and compassion (Exodus 33:19) (Artson 44). God is "compassionate and gracious, slow to anger, abounding in kindness and faithfulness..." (Exodus 34:6) (Artson 45). Jews agree with process thought that "God relates to humanity 
primarily through love..." (65); "The entire Jewish tradition is that God creates the world, we are told, in order to have an object to love" (69).

God's own goodness and lovingkindness are so compelling that spiritually sensitive persons accept God from deep within without being coerced or threatened from without (Artson, 91, 97-100, 104). They freely affirm and live out the biblical injunction, "You shall love the Holy One your God" (Deuteronomy 6:5) (Artson 35). Without being explicit about it, Artson here cites words that are integral to one of Judaism's most fundamental and sacred texts, one of its most often repeated prayers, the Shema. The first two verses of it (Deuteronomy 5:4-5) read as: "HEAR, O ISRAEL: The LORD our God, the LORD is one. You shall love the LORD your God with all your heart and with all your soul and with all your might." Thus, God is intrinsically valuable, and we are to evaluate God intrinsically. Though he writes primarily for a Jewish audience and affirms that God has a special love for the Jewish people, Artson also makes it clear that "God is God, for everywhere and everyone" (112). Still, Jews are special to God because God has chosen them to be a blessing to all nations, as indeed they actually have been through the centuries (106, 109ff, 147ff).

Artson's main project is "to make a Process Theology argument for why, as Jews, love is important: what it is that love entails; and how we might foster a more persistent and resilient love to heal this broken world and to bring wholeness to shattered hearts" (64). As Artson recognizes, "Love is the central reality of Process Thought" (64). Significantly, process thinkers acknowledge that all love, including God's, involves real feelings, despite the Aristotelian "impassibility" that classical Jewish and Christian theology attributed to God $(6-7,15)$. Artson agrees that Process Theologians are on the right track here. According to Artson, "Over and over again, the Torah emphasizes a God who expresses emotion, who meets people in relationship, and changes because of that relationship" (15).

Artson thus appreciates Process Theology's affirmation that both God and the world change. God is also in process (God's "consequent nature") even though God's abstract "primordial nature" is everlasting and unchanging. God's decisions, experiences, and responses change as the world changes, but his general abstract "attributes" endure forever (xvii). Artson insists that the true meaning of "Y_H_W_H" must convey "the flowing temporal nature of God's holy becoming and the timeless quality of God's essence" (xvii). Artson seems to follow Hartshorne in ascribing all of God's abstract attributes to God's primordial nature, instead of limiting it, as did Whitehead, to nothing more than God's primordial 
envisagement of eternal objects. This means that some desirable aspects of God do not change everlastingly, but God's experiences and decisions change as God acts upon the world and interacts with its people and other creatures in real time and history, not from the vantage point of a timeless "everything all at once" eternity. And these changes are also desirable. Classical theologians say that God acts on the world, but the world never acts on God. Process and Jewish theologians should and do think otherwise, says Artson. The Jewish people have always experienced God historically and temporally, and Artson believes with biblical writers and today's Process Theologians that God's biblical dynamics must not be dismissed as an illusion, as it is in Classical (non-process) Theology, both Jewish and Christian. As he wants to show,

Significant strands within Judaism have always been inherently Process. I look at some major aspects of Judaism-the Jewish relationship with God; the Jewish understanding and commitment to covenant; rituals and observances, including prayer, mitzvot, and holy days; the Jewish relationship to Israel; our understanding of mortality and meaning; the importance of community and the pursuit of justice - and illustrate a way of life, a cultural and spiritual expression, that from its very roots is dynamic, interconnected, and in continuous relational change. (xviii)

The Classical theological claim that God is "impassible" (derived from Aristotle, not from biblical religion) implies that God has no feelings, that God does not change in any conceivable way, and that God is omnipotent in the sense that God both has and exercises all power $(6-7,123)$. This leaves human beings and other creatures with no self-determining freedom or moral responsibility for what they choose to do. God is also omniscient, which classically means that from eternity God already knows absolutely everything, so God neither learns nor gains anything from interacting with creation and its creatures. In fact, there is no interaction at all in Classical Jewish and Christian theology; there is only one-sided action of God on the world-predestination. There is no self-determination by or creative self-origination within creation and its creatures. The God of Classical Theology, Artson says, is "a bully in the sky" (17). Process Theology rejects all of this and reconceives of God's power, dynamics, and knowledge in ways that allow us to be co-creators with God. God gladly shares power and creativity with us, and God learns of our free decisions only when and as they are made and of our deeds only when and as they are done. 
"God's primary mode of power is persuasive, not coercive" (xvi, 17), Artson stresses. God lures us toward what is best but allows us to choose what is less than best (41). God created us to be partial creators of our own destinies through the free decisions and efforts we make and the free actions we perform (xvi, 11-12). The God of Judaism "is not an allpowerful, impassible, eternal God, but a God so connected through relationship that the best way to describe this temporal, passionate covenant partner is in the language of love and law" (19). The Jewish scriptures make it clear that God has real feelings, suffers with us in our sufferings, and is hurt by our moral and spiritual sins and shortcomings (19-20, 30-34). In being responsive to changing creation, God changes, according to biblical religion. Despite what some Greek philosophers thought, some changes are desirable. Regrettably, Classical Jewish and Christian theologians agreed with the Greeks that perfection is absolutely unchangeable, but this is not the biblical understanding of God's perfection. As Artson says, "Love changes when it finds need to changea responsive vulnerability" (70), and this applies to both divine and human love.

God is omnipresent, that is, present with and responsive to those who suffer and weep. God is also present with those who rejoice and are happy. The Biblical view is that God is both transcendent beyond and immanent within the created world. The prophet Isaiah proclaims, "Holy, holy, holy - the Holy One of Hosts, God's presence fills the world" (Isaiah 6:3) (Artson 14). God is present not only with and in us but with and in all creation: "As transcendent as aspects of God may be, much of God is also immanent. God is to be found in each and every flower, in every breath we take, in the people who are sitting next to us, and in a world that God has made for us" (78). God is present with and within and values us even in our embodiment. There is a large "consensus within Jewish tradition" that rejects Platonic/Cartesian soul/body dualism and affirms that "People are not disembodied spirits but rather bassar ve-dam, flesh and blood, an inextricable fusion that constitutes God's crowning glory" (78); thus, "Rabbi Elazar said, a person should always see himself as if holiness resided within his intestines" (79). There is nowhere we can go to escape from God, for God's presence penetrates and pervades everyone and everything through and through — but without overwhelming us.

Viewing this Jewish/Process perspective on God axiologically, all of 
the above "attributes" are among the most important good-making or perfect-making properties of Supreme Goodness. In Hartmanian Axiology, good-making properties are the descriptive properties that some reality ideally must have in order to be good, or, in this case, perfect. (Axiologically, to paraphrase St. Anselm, God is that being than whom none richer in perfect-making properties can be conceived.) Exactly what these good- or perfect-making properties are varies from one potentially good thing to another. Good or perfect realities are those that fulfill the ideal standards that we apply to them. God's attributes, as we understand them, are God's perfect-making properties. The One Intrinsic Reality who exemplifies or fulfills all the ideal properties (and more) in our concept of God is Supremely Good or Perfect. In sum, in light of Process Theology, Jewish Theology, and biblical religion, God's basic perfect-making properties, as identified in the preceding paragraphs, are these: God

1. is loving, gracious, compassionate, slow to anger, kind, faithful, and Holy,

2. loves everyone, but has a special love for the Jewish people as blessings to all humanity,

3. changes in experiences and decisions in response to creation but is unchanging in very general attributes,

4. knows eternal things everlastingly and temporal things temporally,

5. has real feelings, including those involved in love and compassion,

6. suffers with those who suffer and delights in and with those who are righteous and happy,

7. commands and commends thoughts, beliefs, feelings, actions, and ritual practices that express and manifest reverence, devotion, love, compassion, justice, and other moral and spiritual virtues, 8. freely creates constantly and allows us to be partly free, creative, and self-determining,

9. has and exercises power that is both creative and persuasive but not coercive, and

10. is constantly present with and in all.

These are central features of the Jewish/Process concept of God. 
Obviously, this list is not exhaustive, and it could never be, for, as Rabbi Artson says, God is "the One who exceeds all verbal description" (xvii) and "God's perfection is beyond all human assertion or articulation" (77). Even so, with humility we try to conceive of and understand God as best we can, while recognizing with Whitehead that our understanding of ultimates can never reach a "final formulation" (PR 4, 9, 3, 20, 193). Also each numbered item above could be broken down or analyzed into many other numbered items. Exact numbers for God's attributes, i.e., for how we divide our understanding of One God into many parts, really don't matter. Our concept of "One Supremely Good and Holy Intrinsic Reality" is exceedingly complex, infinitely complex, as is the God who fulfills this concept - and more. As thoroughly documented in his book, Rabbi Artson shows that this dynamic concept of God is strongly supported by both Jewish scriptures and ongoing rabbinical writings and traditions.

\section{The Intrinsic Value and Evaluation of Individual Persons}

Rabbi Artson says that "Jewish beliefs are abiding affirmations. God is always One, the Torah was given to Moses..." (136); and "We Jews are commanded to love" (73). He proclaims, "Judaism boldly insists on love at its core and then implements that love personally and communally, through mitzvot [commandments] of spiritual intimacy and social justice" (62). God loves us (65), and "We are called to embody God's image. We are called to be like God, sources of bounty and blessing for others: 'Be a blessing ... and in you shall all the families of the earth be blessed" (Genesis 12:2-3) (Artson 72-73, 109-110). That is the essence of God's special relation with the Jewish people. But love is not simply how Jews (and all the rest of us) are to evaluate God; it is also how we are to evaluate one another-lovingly, intrinsically, with the most profound thoughts or concepts, and with the most intense feelings of love, compassion, and self-identification with others, and with actions that express all of these. Artson cites Leviticus 19:18 and Deuteronomy 10:19, which command us to love our fellows, even strangers, as we love ourselves $(51,151)$. All of God's commandments or mitzvoth "remain what they have always been: commandments of love; trusted pathways connecting the Jewish people and much of humanity with the God of Israel; beacons lighting lives of justice, compassion, and holiness in a world too often cruel and harsh" (100). One might still wonder, however, if some scriptural mitzvoth are not more loving than others, and Artson 
begins to get into that when he acknowledges the "rabbinic activism" of the "Rabbis of the Talmud" and praises them for "creating a technical method for liberating slaves when the Bible explicitly forbids it (Berakhot 47b, Kiddushin 22b, Gittin 401 and 43b), and creating a way to bequeath property to daughters, despite an explicit biblical prohibition (Ketubot 681)" (Artson 54).

Although he does not explicitly use the language of intrinsic, extrinsic, and systemic values and evaluations, Rabbi Artson does say, "Each person's worth is more than merely instrumental,...each Jew, each person, each living thing, expresses perpetual worth as a manifestation of God in the world" (88). He is keenly sensitive to the uniqueness of human (and other) individuals. In Hartmanian Axiology, uniqueness is a primary value concept, and it is applied to every human being. Mere individuals may be nothing more than numerically distinct members of a given class, but unique individuals are in a class all their own. Using dictionaries, we can count the number of words or property-concepts required to define class concepts and their members, but the number of words or propertyconcepts required for fully understanding any unique human being are so great as to be practically uncountable, though not literally infinite (despite what Hartman thought). Most Jewish and Christian theologians have emphasized God's infinity and human finitude, and I fully agree, as explained elsewhere (Edwards 2010, 67-82). Yet, the details of each unique person's life are so immense as to be practically uncountable.

Hartman wrote of "x's self, i.e., the integral totality of all of x's attributes" (Hartman 1991, 15), so perhaps the best axiological account is that each unique individual person is the integrated totality of all of his or her properties (qualities and relations). In short, we are "our integrated total property inventory" (Edwards 2014, 64-84). Even if that totality is not infinite, it is still too great to be counted in practice. Our total property inventory includes every experience we have ever had, every thought we have ever thought, every choice we have ever made, every feeling and emotion we have ever felt, every deed we have ever done, and much more. The desirable ones are our good-making properties, but who could ever count them? (The undesirable ones are our bad-making properties.)

In his own way and words, Rabbi Artson is very sensitive to the fullness, richness, definiteness, and concreteness of every human being. He repeatedly affirms that this sensitivity belongs to the whole tradition of Judaism, not just to himself. As he explains "Each of us is a dynamic 
composite of everyone we've known, every place we've been, in expanding circles of family, community, species, and planet" (127); and "The totality of each of our identities comprises more than a single characteristic. Each of us integrates different partial identities...I am a Jew, an American, male, human, father, son, husband, and friend. All those attributes inform who I am, so the best way to know me is to multiply these complementary descriptions, add them to each other, producing a rounded, cumulative picture of the person I am" (120). Of course, any unique person's integrated totality of descriptive good-making properties vastly exceeds those in these brief lists, so much so as to be practically uncountable.

Artson does not recognize that there are some serious philosophical problems about what counts as morally and spiritually significant "individuals" in process thought. Are real "individuals" only fleeting temporal "actual occasions," as Whitehead claimed, or do more enduring whole persons count as "individuals"? (Edwards 2014, 61-64) For Whitehead, whole persons are not true individuals; they are only vast societies of actual occasions. I try to develop a plausible process alternative to this in my An Axiological Process Ethics (Chs. 1, 2). Perhaps human souls and whole human persons are vast and relatively enduring spatio-temporal soul-fields, not mere societies of fleeting actual occasions. In previously given quotes, Artson seems to have whole persons, not actual occasions, in mind as "individuals," which I think is the best option. He suggests that both he and Judaism agree with Process Theology that "God knows and relates to us as individuals" (xvi, 54) and God is "so personal that God meets each of us in our immediate concrete particularity; who we are at this moment, what we need now to take the next step forward. That means that at every instant, God knows us (and every event or actual entity in creation) not theoretically, not in a timeless theoretical way, but as we actually are — each of us, all of us" (124). Just as God is in process, so are we, for, as enduring whole persons, enduring actual entities, our total property inventory is constantly increasing as time marches on.

Conceiving of and valuing others and ourselves as unique enduring individuals makes a practical difference in many ways. For one thing, if love is to express and embrace uniqueness, "Love must be grounded in the entirety of who we are-our memories, character, experiences, body, temperament, and aspirations. Our love must also be grounded in our integrity - in the authentic selves we are in private and in public" (71-72) 
and this involves "inviting others to rise similarly to their unique greatness" (72). Valuing our uniqueness is not egoism. We do indeed value ourselves, perhaps at times too much; but our self-transcending moral virtues, social relations, and concerns for the wellbeing of others also clearly belong to our total unique property inventories (98). By nature and grace, we are moral, spiritual, and social beings in constitutive relations with others. Judaism, Process Theology, and Formal Axiology commend the actualization of our best potentials, including our moral and spiritual potentials for loving God and all others, both neighbors and strangers. Says Artson, "We Jews are commanded to love," (72) and "Love works its transformative magic as we grow to love ourselves, body, and soul. Love spawns the work of social justice as we learn to love our fellow creatures, their character, and their corporeality. Love emerges as cosmic identification as we work to implement our love for this planet and its denizens in their physical reality. Bodies matter when it comes to love" $(72,122)$.

Artson recognizes that many people value universals (Whitehead's "eternal objects") more than unique individuals, but this perspective this has serious "drawbacks," the first and foremost of which is:

If the ideal is only located in the universal, then every particular example is automatically inferior, implying that your deficit is located precisely where you are uniquely different from all other people. Someone who loves technology more than the average is a nerd; someone who is physically demonstrative is a fruitcake, and so on. Distinction is automatically viewed with suspicion or derision. A view that elevates the ideal [the universal] is profoundly mistrustful of any individuality, of people being stubbornly not the ideal, of being irreducibly unique and different.

One of the strengths of Formal Axiology is its clear recognition that intrinsically valuing unique persons is also an ideal, and we have at least a dim concept of everyone's uniqueness and how best to further actualize it, including our own. We also realize that this ideal can be fulfilled, or not. Hartman characterized "intrinsic value" as "the fulfilment of the singular intension" (Hartman 1967, 254). Singular intensions are so rich in goodmaking properties that we cannot in practice count all of the ways in which we can and should be "true to ourselves," something which Hartman frequently emphasized. Not just my self-realization through time, but everyone's, has incalculable intrinsic worth. As I understand him, 
Rabbi Artson thinks that Judaism and Process Thinkers share this perspective, this intense valuation of unique persons, expressed, of course, in their own and his own distinctive ways.

\section{Jewish Extrinsic Values, Value Combinations, and Value Rankings}

In the abstract, extrinsic values are things that are useful. Hartman insisted that anything can be valued as if it belongs to any value dimension. Thus, any intrinsically good thing can also be valued as useful. However, some good things are distinctively extrinsic in the sense that being a means to ends beyond themselves is our primary reason for valuing them. Hartman thought that distinctively extrinsic values were enduring objects, processes, and actions within the objective or public sensory world. Process Thinkers regard them as "aggregates," physical objects and processes without dominant "souls," as Whitehead called them (Edwards 2014, 84-90, 102-104). Extrinsic goods are sensory goods. For present purposes, these fall into two groups, first, soul-less physical things and processes, second, visible human bodies, actions, or behaviors. As Artson explains, physical things can be valued intrinsically as manifestations of the presence of God. He quotes an ancient Rabbi as saying, "Do not say, 'This is a stone and not God.' God forbid! Rather, all existence is God, and the stone is a thing pervaded by divinity" (15). However, our immediate concern is with valuing sensory things, processes, and actions extrinsically as means to goals or objectives beyond themselves.

First, how do Jews value physical "aggregates," objects, and processes extrinsically? Aside from having normal and universal human interests in material things that have survival value and contribute to overall prosperity, comfort, and enjoyment, Jews also employ purely physical objects and processes in their own distinctive religious situations-partly because they are morally, spiritually, and culturally useful. Significant physical things belong to their Jewish heritage and help them as individuals to belong to their own tradition. They help them to understand and express who they are.

The universe that God created is both physical and sensory, and it is good, as Genesis 1 declared. The Ten Commandments were originally written on tablets of stone, so says the Torah. The Ark of the Covenant was a physical and sensory thing, as was the temple in Jerusalem, and as are synagogues today. So are menorahs, phylacteries, prayer shawls, burial shrouds, yarmulkes, traditional attire for Orthodox Jews, and many other physical/sensory objects and processes that have great significance 
within Judaism. All such things can be viewed as useful within Jewish culture, practices, and traditions. In practice, they are effective means for connecting with and expressing one's Jewishness and Jewish spirituality. However, their merely extrinsic worth is typically supplemented by additional values and evaluations. As religiously significant, they are complex value combinations. Two other things are required for physical/sensory objects and processes (aggregates) to have the real religious significance that they have within Judaism. First, they must be imbued or infused with systemic value-objects-with Jewish beliefs, ideals, traditions, and ritual forms. Second, practicing Jews must intensely, personally, lovingly, and intrinsically identify themselves with them if they are really going to work spiritually and morally.

For present purposes, the second basic kind of extrinsic value-objects consists of human bodily functions, actions, and behaviors. These must also be imbued or combined with systemic and intrinsic values in order to have real spiritual, moral, or cultural significance. Circumcising (148), for example, is a physical process, but for Jews it is far more than that. Considered merely for their extrinsic worth, human bodily behaviors are means to personal, moral, spiritual, traditional, etc., ends or objectives. Yet, they always function in broader axiological combinations. Truly significant bodily behaviors are saturated or combined with systemic forms - moral, spiritual, doctrinal, ritual, conventional, cultural, etc. This is how they find expression in Jewish worship services both in synagogues and in homes. Rituals have two sides; they are both forms (formulas) and visible practices. The communal practice side of them is both physical and sensory. As in process thought, Judaism has no prejudices against physical and sensory things, including human bodies (75-81) for "bodies are sacred" (80). Sensory things created by God are good, not evil (as some non-Jewish thinkers believed). As Rabbi Artson recognizes, "Most Jews today, when they light Shabbat candles, eat a kosher meal, contribute tzedakah [obligatory giving or charity], or feed the hungry celebrate that they are linking themselves to something beyond themselves-God, Jewish values, creation as a whole, holiness" (98). Artson recognizes Judaism's "detailed regimen of behavior that shapes every aspect of our waking lives..." and "even specifies permissible body postures while asleep" (91).

So, in Judaism, extrinsic observable human behaviors are integrated or saturated with systemic conceptual forms-beliefs, ideals, rules, laws, commandments, rituals, systems, etc. They are also integrated and infused 
with intrinsic evaluations involving feelings and profound selfidentification with valued objects. When our hearts are not in them, as is sometimes the case, going through the motions seems empty and pointless. As Rabbi Artson says, "Jewish Love Integrates Our Inner Emotions with Deeds" (70). He further explains, "Love is the ability to integrate all our powerful emotions in consistent, empathic behavior. Our emotions inspire us to act. Our actions hone and temper our feelings. The cycle is never static and never ending" (71). Again, "Love (ahavah) ripens into lovingkindness (chesed)" (71). Jewish systemic and intrinsic values and evaluations issue in extrinsic, sensory, physical, public actions. The "crowning glory" of the Torah and the Rabbis is "to focus Jewish life not in people thinking abstractly together but in doing deeds of lovingkindness and holiness" (80). Committed Jews do the works of love, compassion, and social justice. "The peak of Sinai, it turns out, is ethics, as the prophets themselves also emphasize. In Jewish religious understanding, ritual matters because it generates ethical seriousness; it creates a pedagogy of goodness and an agenda of grateful inclusion. Our beliefs enter life through our deeds" (104).

\section{Jewish Systemic Values, Value Combinations, and Value Rankings}

In the abstract, systemic values are mental or conceptual goods. They have always had a prominent place within Judaism. As Rabbi Artson recognizes, "Judaism has, throughout the ages, always placed a high value on ideas, on the life of the mind. Judaism has linked the spiritual enterprise with that of intellectual rigor. This has been a crowning glory of Jewish civilization and one that we ought to continue to celebrate" (76). Jews have always valued education highly, and many have been profound thinkers, philosophers, theologians, scientists, writers, musicians, and artists, etc. In Judaism, serious study of Jewish scriptures and sacred writings begins at an early age and continues throughout life (149). Still, in his own words and way, Artson warns against overvaluing Jewish systemic or conceptual values at the expense of Jewish extrinsic and intrinsic values.

Artson's book implicitly contains a partly developed hierarchy of value that corresponds with that of Robert S. Hartman. According to Hartman, intrinsic values (e.g., people) have more worth than extrinsic values (e.g., sensory objects and behaviors), and extrinsic values have more worth than systemic values (e.g., ideas, ideals, beliefs, rules, formalities). This is because people have more real good-making 
properties than mere things and behaviors, and these in turn have more real good-making properties than our conceptual symbols or words for them.

Thus, when faced with conflicts between these three kinds of value, people should always have priority over mindless aggregates, and both people and mindless aggregates should have priority over our conceptual symbols for them. These three kinds of value, intrinsic, extrinsic, and systemic are quite distinct from and, should not be confused with the three sorts of value that Whitehead had in mind when he affirmed, "Everything has some value for itself, for others, and for the whole" (MT 111). The three value dimensions can be related to the goodness of self, others, and the whole in various ways. For example, though debatable, we might say that every individual, every other experiencing actuality, and the whole set of all experiencing actualities has value to itself for its own sake, is useful to itself, and has some kind of abstract knowledge of itself. All can have a corresponding three-dimensional worth to others.

There is at least one debatable issue about "the whole." By this, did Whitehead mean "the cosmos," the whole of nature, or did he mean God, as inclusive of all things - all individuals, all others, the whole of creation? For the moment, consider only the rest of the cosmos. Ethically, we know how to act to affect the well-being (or ill-being) of individuals and communities of individuals in our local earthly setting. For example, we can love and have compassion toward all individuals and act accordingly; we can try to promote the prosperity of all; we can do our best to impart knowledge, beliefs, and constructive rituals to all. As far as the rest of the cosmos is concerned, we can rejoice that distant others saturated with values are out there, but what could we now do to enhance the wellbeing of other experiencing entities in galaxies far far away? We have no clue, for the significant moral effects of everything that we can actually do are cosmically local (Edwards 2014, 212-214), despite quantum-level non-locality and Whitehead's insistence that "Every actual entity is present in every other actual entity" (PR 50). (Artson does not deal with such matters.)

Artson does deal with problems about what we should do when intrinsic, extrinsic, and systemic values come into conflict, for he ranks them in accord with Hartman's hierarchy of value. However, he does not tell us what to do when what is good for me comes into conflict with what is good for others or for the whole of reality. Neither did Whitehead, though he recognized the possibility of conflict when he acknowledged 
that "Life is robbery," and that "The robber requires justification" ( $P R$ 105). Regrettably, he did not tell us explicitly what that justification is. In the abstract, a justification actually is available in Whitehead's, "Morality consists in the control of process so as to maximize importance" (MT 1314). The abstract solution is: When what is good for me conflicts with what is good for others, we should just do what is best. This abstract solution is also available to Rabbi Artson, who frequently commends doing what is best $(17,41,58,125)$. Presumably it is best for us to eat plants than to die; such robbery is morally permissible; but eating animals when not necessary for our survival is another matter altogether, as vegetarians eagerly point out. Making explicit, "Do what is best when values conflict," in concrete particular cases would be immensely complex and would require many volumes of Talmud and casuistry. I deal with some relevant issues like abortion, terminal cases, unrelievable suffering, and ethics and animals in Chapter three of my An Axiological Process Ethics, but all of that is far beyond the scope of this essay.

To conclude, let us take a look at Artson's ranking of intrinsic, extrinsic, and systemic values, and at his resolution of their possible conflicts. As for extrinsic values, the intrinsic worth of individuals clearly has priority over the extrinsic. Rabbi Artson says, "You may not indenture yourself to wealth, fame, prestige, social status, or habits. You have been set free" (145).

As for systemic values, according to Artson, extrinsic values like good deeds rank higher than systemic values. Discussions of the mitzvot or "commandments" are customarily introduced "by noting that in Judaism the deed is central whereas theology remains secondary" (91) - a clear ranking of the extrinsic over the systemic that also appears in Artson's "the priority of the ethical over the ritual in Jewish tradition," "The Talmud clearly place the ethical over the ritual" (52); "Ritual matters because it generates ethical seriousness" (104); and "The Rabbis perceive God as preferring righteous behavior to correct belief" (34). Artson also emphatically affirms the necessity for systemic/extrinsic value combinations: "As though thought and deed could ever be completely separated - a fuller Process understanding of Judaism as a way of life invites us to recognize the dynamic, almost organic way that thought and deed interrelate in a confluence richer than either would be alone" (92) and "The whole is greater than the sum of its parts" (95).

As we have seen, intrinsic values, whole persons and God, clearly rank highest in Judaism. Artson affirms this on many pages of his book 
(xvi, 54, 82-83, 88, 125-125, 128). For moral and spiritual effectiveness, not only must Jewish systemic and extrinsic values be combined with each other, but both must be combined in turn with intrinsic values and evaluations. Jewish commandments and "laws" are not obeyed for their own sake, or merely for their usefulness in promoting prosperity and social solidarity. No, they are (or should be) obeyed primarily out of love for (intrinsic valuation of) God and for one another (finite intrinsically valuable realities). "Mitzvot are commandments because we are loved with an everlasting love and because we are inspired to yearn for God's intimacy and illumination. Love creates imperatives that ripple out from the core of our loving hearts, which is precisely where God abides. Love obligates from the inside, as caring and nurturing warm from within" (99). Commandments and beliefs may also be valued intrinsically; the Torah itself should be accepted "with love and affection, with fear and reverence, with awe and trembling" (105). In discussing prayer, direct interpersonal relations with God are ranked higher than the beliefs that we often bring to the process: "Our moments of sincere outpouring are more real than the ideas we filter those acts through" (123). Of course, as Artson explains, we might be able to develop and incorporate a better theology, better ideas about God, into our praying (134), and he has shown effectively that Process Theology definitely helps. So can Hartmanian Formal Axiology.

\section{Conclusion}

No doubt, the preceding discussion does not do full justice to the richness and completeness of Rabbi Artson's book or to Judaism itself. Indeed, its author, not being Jewish, has poor credentials for even attempting to write about the issues here celebrated and examined. Yet, perhaps enough has been said to inspire others with better qualifications to further explore relations between Judaism, Formal Axiology, and Process Theology. Perhaps enough has been said to indicate and express the author's own best attempt, however inadequate, to begin to understand and greatly appreciate Judaism, and to integrate it with these two mutually compatible and complementary philosophical perspectives. 


\section{WORKS CiTED}

Artson, Bradley Shavit (2013). God of Becoming and Relationship: The Dynamic Nature of Process Theology. Woodstock, VT: Jewish Lights Publishing.

Edwards, Rem B. (2014). An Axiological Process Ethics. Claremont, CA: Process Century Press. (2010). The Essentials of Formal Axiology. Lanham, MD: University Press of America.

Hartman, Robert S. (1991). "The Nature of Valuation." In Rem B. Edwards and John W. Davis, eds. Forms of Value and Valuation: Theory and Applications. Lanham, MD: University Press of America. Republished in 2014 by Wipf \& Stock, Eugene, OR.

(1967). The Structure of Value: Foundations of Scientific Axiology. Carbondale, IL: Southern Illinois University Press. Republished in 2011 by Wipf \& Stock, Eugene, OR.

Whitehead, Alfred North. Modes of Thought (MT). New York: The Free Press, 1968.

Process and Reality, Corrected Edition (PR). New York: The Free Press, 1978. 